\title{
Applying SWAT to predict ortho-phosphate loads and trophic status in four reservoirs in the upper Olifants catchment, South Africa
}

\author{
J. M. Dabrowski \\ Natural Resources and Environment, CSIR, P.O. Box 395, 0001 Pretoria, South Africa \\ Correspondence to: J. M. Dabrowski (jdabrowski@csir.co.za)
}

Received: 7 October 2013 - Published in Hydrol. Earth Syst. Sci. Discuss.: 12 November 2013

Revised: - - Accepted: 5 June 2014 - Published: 16 July 2014

\begin{abstract}
Excessive phosphate loading in the upper Olifants River, South Africa has resulted in widespread eutrophication and associated ecosystem health impacts. The majority of sewage treatment works (STWs) are operating poorly and are likely an important source of bioavailable orthophosphate (OP) in the catchment. The Soil Water Assessment Tool (SWAT) was used to identify important sources of OP loading in the catchment and to predict changes in the trophic status of four reservoirs associated with three STW effluent OP standards (the current average of $4 \mathrm{mg} \mathrm{L}^{-1}$ and standards of 1 and $0.1 \mathrm{mg} \mathrm{L}^{-1}$ ). Nash-Sutcliffe and PBIAS statistics showed good model performance for simulations of flow and OP loading using a multi-site calibration and validation approach. Key sub-catchments responsible for high OP loading were identified. Three of the four reservoirs are heavily impacted by OP loading originating from STWs. Two reservoirs show mean annual OP concentrations indicative of eutrophic conditions and a $1 \mathrm{mg} \mathrm{L}^{-1}$ effluent standard would reduce concentrations to well within the mesotrophic range. There was little difference in OP loads and concentrations associated with the 1 and $0.1 \mathrm{mg} \mathrm{L}^{-1}$ effluent standards, indicating that attention to nonpoint sources would be required to realise any benefit associated with the strictest effluent standard. Regression analyses and associated $95 \%$ prediction limits between simulated OP loads and concentrations for all effluent treatment scenarios from 2002 to 2010 allowed for the quantification of OP loading that would ensure a specific trophic status in each reservoir. This study is one of the first to apply SWAT in simulating OP loading and concentrations in large reservoirs, and its application in South Africa provides further support for its utility throughout a wide geographical area.
\end{abstract}

\section{Introduction}

Nutrient pollution and the proliferation of algal blooms associated with eutrophication are considered to be two of the greatest threats to water quality in South Africa (van Ginkel, 2011). Phosphorus is the limiting nutrient in freshwater systems and anthropogenic inputs thereof are the most important driver with regards to managing eutrophication in lakes, reservoirs and rivers (Carpenter et al., 1998; Mainstone and Parr, 2002). While total phosphorus is most commonly used as an indicator of trophic status in reservoirs and lakes, it is well known that ortho-phosphate (OP) is the most available form of phosphorus and is the primary driver of algal productivity in freshwater systems (Reynolds and Davies, 2001). OP concentrations have shown an increasing trend in most primary catchments across South Africa (de Villiers and Thiart, 2007). Nonpoint source agricultural runoff containing nutrients derived from fertiliser and manure and point source effluent originating from sewage treatment works (STWs) are typically the most important sources of phosphorus pollution in freshwater systems (Hart et al., 2004; Jarvie et al., 2006). Furthermore, mining and the concurrent removal of vegetation and exposure of bare soil and rock to weathering and soil erosion also result in the potential for relatively high losses of naturally occurring phosphorus in the soil, similar to what would be expected at large construction sites (Carpenter et al., 1998).

Water quality in the upper Olifants catchment, located in the Mpumalanga Province of South Africa, is significantly impacted by a number of land-use activities occurring in the catchment (Dabrowski and De Klerk, 2013). The catchment is currently the most important source of coal in the country (Hobbs et al., 2008) and also supports associated coalfired power stations, metallurgical industries and large urban 
towns as well as dryland agriculture and cattle production in grassland areas. The majority of STWs are operating at a poor standard, releasing high volumes of partially treated effluent into river reaches (DWA, 2010). The effects of these intensive anthropogenic activities have been most pronounced in the Loskop reservoir, located at the bottom of the catchment, where water quality has steadily declined (Dabrowski et al., 2013). In particular, eutrophication has become more prevalent since 2008, resulting in regular blooms of Microcystis cyanobacteria during the summer months (Oberholster et al., 2010). These blooms have been associated with increased frequency of fish kills (Ashton, 2010) and blockage of canals and deteriorating water quality in the irrigation scheme downstream of the reservoir (Oberholster and Botha, 2011). Further downstream in the Olifants River, close to the border with Mozambique, widespread crocodile deaths have occurred in the Kruger National Park (Ferreira and Pienaar, 2011). These deaths have been ascribed to pansteatitis (a nutritionally mediated condition characterised by necrosis and inflammation of the adipose tissues), the cause of which has tentatively been linked to alterations in the food web associated with the proliferation of algal blooms (Huchzermeyer et al., 2013). Crocodile populations have also declined in the Loskop reservoir and diagnosed mortalities have also been ascribed to pansteatitis (Ashton, 2010; Botha et al., 2011). The recent occurrence of algal blooms in the reservoir and associated alarming ecosystem impacts have necessitated an urgent need to identify sources of phosphorus in the catchment and to investigate management options capable of reducing phosphate loading in an attempt to maintain algal productivity and trophic status at acceptable levels.

In this respect, hydrological water quality models have been increasingly used to simulate the influence of land-use activities on flow and point and nonpoint source pollution in large catchments. Most importantly, once calibrated and validated, these models are especially useful in evaluating the effectiveness of proposed management plans or practices and how they could influence an ecological endpoint of concern. The Soil Water Assessment Tool (SWAT) (Arnold et al., 1998), while developed in the United States, has been widely and successfully applied to simulate mainly hydrology and to a lesser extent sediment, nutrient and pesticide loading in numerous catchments throughout the world (Arnold and Fohrer, 2005; Gassman et al., 2007). Additionally, SWAT is capable of simulating nutrient concentrations in large reservoirs, an application that makes it suitable for linking nutrient loading with trophic status. However, only one study has examined the feasibility of applying SWAT to predict OP loading to a reservoir (Daloğlu et al., 2012) and no studies have applied SWAT to estimate OP concentrations in a reservoir. Furthermore, very limited studies exist on applying SWAT to simulate nutrient loading in an African catchment.

The aim of this study was therefore to investigate the suitability of applying SWAT to identify important sources of OP loading in the upper Olifants catchment, South Africa.
Considering the likely importance of STWs as a source of OP in the catchment, scenario analysis was carried out to determine the impact of improved STW OP effluent standards on load reductions and associated trophic status in the four reservoirs in the catchment. Modelling outputs were compared against routine monitoring data from multiple sites so as to calibrate the model input parameters and validate the model output results.

\section{Methods}

\subsection{Study area}

The study area for the modelling exercise was confined to the catchment of the upper Olifants River, upstream of the Loskop reservoir (Fig. 1). The impact of land-use activities and point source pollution from STWs on OP loads and concentrations in the Bronkhorstspruit, Middelburg, Witbank and Loskop reservoirs (with capacities of 57.91, 48.44, 104.02 and $361 \times 10^{6} \mathrm{~m}^{3}$, respectively) was investigated. The reservoirs are regulated, with Loskop providing water to the second largest irrigation scheme in South Africa, while the other reservoirs supply water for domestic and industrial use. The land use in the catchment is dominated by grassland $(\sim 50 \%)$ and commercial dryland agricultural crop production $(\sim 37 \%)$, interspersed with areas of urban development $(\sim 1.6 \%)$, coal mining $(\sim 2.8 \%)$ and mixed natural Loskop Thornveld (deciduous to semi-deciduous thorny woodland) and Loskop Mountain Bushveld (open to broad-leaved savannah) vegetation $(\sim 8.3 \%)$. Grassland is located throughout the catchment, but together with thornveld and bushveld vegetation is mainly located in the northern section of the catchment. Dryland agriculture is located primarily in the middle to upper reaches of the catchment, consisting mainly of maize production, which is the primary source of nonpoint source pollution, particularly during summer storm events. Mining is most intensive in the central reaches of the Olifants River and in tributary catchments of the Klein Olifants River. The towns of Middelburg and Witbank are the largest urban areas in the catchment and a number of other smaller towns are located across the catchment. STWs are located throughout the catchment, the majority of which are municipal, with a few associated with large mines and industries (e.g. coal-fired power plants). STWs contribute a volume of approximately $7 \%$ of mean annual runoff to the catchment (DWAF, 2004). The catchment falls within a summer rainfall area, with the majority of the $680 \mathrm{~mm}$ of mean annual rainfall occurring from October to April. Soils are predominantly deep, red to yellow sandy soils represented by the Hutton soil form, with Mispha forms located in the southern extremes of the catchment. 


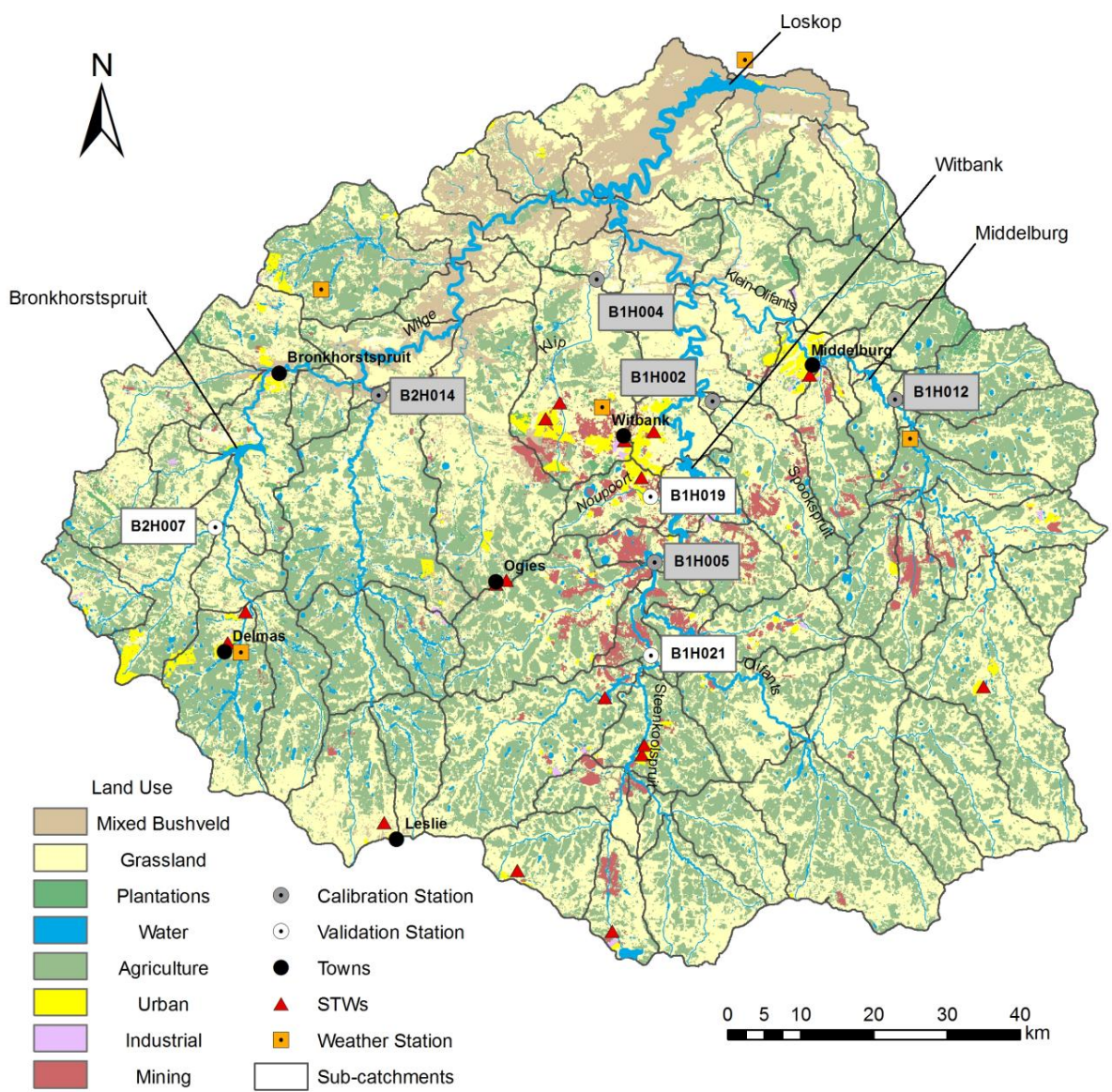

Figure 1. Sub-catchments (delineated by the SWAT model) and location of sewage treatment works (STWs), weather stations and DWA flow and water quality monitoring stations in the upper Olifants catchment.

\subsection{Model description and inputs}

SWAT is a semi-distributed, process-oriented hydrological model that has been developed to predict the impact of land management practices on water, sediment, and agricultural chemical yields (including nutrients) in large, complex catchments with varying soils, land use, and management conditions over long periods of time (Arnold et al., 1998). The SWAT model represents the large-scale spatial heterogeneity of the study area by dividing the watershed into subcatchments. The sub-catchments are then further subdivided into hydrologic response units (HRUs) that are assumed to consist of homogeneous land use and soils. Version 2009 of the ArcSWAT interface for SWAT (Winchell et al., 2010) was used to compile the SWAT input files. This is an ArcGIS integrated version of the model that requires input of digital elevation model (DEM), land cover and soil spatial data sets (Table 1). The climatic variables required by SWAT include daily precipitation, maximum/minimum air temperature, solar radiation, wind speed and relative humidity. Additional input parameters include details of land management practices and characteristics of point source contributions (i.e. location and daily loading). More detailed descriptions of the model can be viewed in Abbaspour et al. (2007) and Lam et al. (2011). Details of the theory of modelling processes performed in SWAT can be found in Arnold et al. (1998) and Neitsch et al. (2005).

The DEM was used for automatic delineation of the main catchment into 89 sub-catchments (Fig. 1). The land use, soil and slope maps were superimposed to identify 985 HRUs. Approximately $90 \%$ of agricultural crop production in the catchment was assumed to be maize production (STATSSA, 2006), with planting taking place in the beginning of October after a tillage operation. Fertiliser application was based on recommended application data from the FAO (2005), with an annual $\mathrm{N}$ and $\mathrm{P}$ application of 70 and $55 \mathrm{~kg} \mathrm{ha}^{-1}$, respectively. Grasslands were assumed to be predominantly grazed by beef cattle. Average livestock density was assumed to be 0.1 head of cattle per hectare (for the entire catchment) according to estimated grazing capacity values for South Africa (AGIS, 2011). The location of STWs was identified using the South African Department of Water Affairs (DWA) GoogleEarth enabled water quality data exploration tool (DWA, 2011a). Limited data on OP effluent concentrations 
Table 1. Sources of input data for application of the SWAT model in the upper Olifants catchment.

\begin{tabular}{|c|c|c|}
\hline Data type & Source & Description \\
\hline DEM & ASTER/GDEM (2009) & Digital elevation model $30 \times 30 \mathrm{~m}$ \\
\hline Soil & Middleton and Bailey (2008) & Soil data for South Africa from the WR2005 project \\
\hline Land use & SANBI (2009) & Land cover classifications \\
\hline $\begin{array}{l}\text { Agricultural } \\
\text { census data }\end{array}$ & STATSSA (2006) & $\begin{array}{l}\text { Census data on area and production of crop types per magisterial } \\
\text { district in South Africa }\end{array}$ \\
\hline Weather data & ARC (2012) & $\begin{array}{l}\text { Records from five precipitation, air temperature, solar radiation, } \\
\text { relative humidity and wind speed gauges over a 10-year period } \\
\text { (1999-2010) were used in the model. }\end{array}$ \\
\hline $\begin{array}{l}\text { Point source } \\
\text { concentrations }\end{array}$ & DWA (2011a) & Limited data on point source emissions of ortho-phosphate \\
\hline $\begin{array}{l}\text { Point source } \\
\text { volumes }\end{array}$ & DWA (2009) & $\begin{array}{l}\text { Information on design and actual capacity for effluent volumes for } \\
\text { each STW in the catchment. }\end{array}$ \\
\hline
\end{tabular}

were available for STWs located within the catchment. Based on the available data, an average current OP effluent concentration of $4 \mathrm{mg} \mathrm{L}^{-1}$ was calculated and applied to all STWs within the catchment. Daily discharge volumes were used to estimate daily loading from each STW in the catchment (DWA, 2009). The DWA water quality exploration tool was also used to identify DWA monitoring stations for which both water quality and flow data were available. These data were used to calibrate and validate the model outputs. Daily weather data were obtained for five weather stations located across the catchment. In general these weather stations covered the majority of the catchment apart from the southern and southeastern areas (Fig. 1). Weather data were used to calculate monthly climatic statistics for each weather station using pcpSTAT (Liersch, 2003). For days where data were missing, the built-in SWAT weather generator function used these monthly weather statistics to estimate daily weather. Minimum monthly outflow was set at $1 \mathrm{~m}^{3} \mathrm{~s}^{-1}$ for the Loskop reservoir and $0.1 \mathrm{~m}^{3} \mathrm{~s}^{-1}$ for all other reservoirs. Average monthly consumptive use per reservoir was set at $6.9,7.2,4.5$ and $25.75 \times 10^{6} \mathrm{~m}^{3}$, for the Bronkhorstspruit, Witbank, Middelburg and Loskop reservoirs, respectively (DWA, 2011b).

\subsection{Model calibration}

The model was run for the years 1999 to 2010. The first three years of the simulation were used as a warm-up period, allowing hydrological and nutrient modelling processes to equilibrate, and only model outputs from the years 2002 to 2010 were used in subsequent analyses. The model was calibrated against monthly measured discharge and calculated OP loads at multiple DWA monitoring stations (calibration stations) included in the study area (Fig. 1). Discharge was measured constantly at each station and expressed as total monthly flow. OP samples were collected at frequencies ranging from once to 4 times per month. Corresponding monthly loads were calculated based on the multiple regression methodology using the FLUX32 program (Walker, 1996) which was designed for estimating constituent loads from intermittent quality data and continuous flow data. Model calibration and uncertainty analysis were done using the SUFI-2 optimisation program within the SWAT-CUP software (Abbaspour, 2011). In SUFI-2, uncertainties in input parameters are depicted as uniform distributions, while model output uncertainty is quantified by the $95 \%$ prediction uncertainty (95PPU) calculated at the 2.5 and $97.5 \%$ levels of the cumulative distribution of output variables obtained through Latin hypercube sampling (Abbaspour et al., 2007). SUFI-2 starts by assuming a large parameter uncertainty (within a physically meaningful range), so that the measured data initially fall within the 95PPU, then decreasing this uncertainty in steps until two rules are satisfied: (1) the 95PPU band brackets "most of the observations" (indicated by the $p$ factor, where values are between 0 and 1 , with 1 indicating that $100 \%$ of the data is bracketed by the PPU), and (2) the average distance between the upper (at $97.5 \%$ level) and the lower (at $2.5 \%$ level) parts of the 95PPU is smaller than the standard deviation of the measured data (indicated by the $r$ factor, where a value of less than 1 is considered acceptable). A balance between the two rules ensures bracketing of most of the data within the 95PPU, while seeking the smallest possible uncertainty band. The above two measures were used to quantify the strength of calibration accounting for the combined parameter, model, and input uncertainties. For flow calibration, sensitive parameters influencing peak and base flow were obtained from the literature (Neitsch et al., 2002; White and Chaubey, 2005) and used to calibrate flow simulations for the calibration stations. The approach adopted in the calibration procedure was to continue to run SUFI-2 iterations (1000 simulations in each iteration) until a further improvement in objective functions for one calibration station was not possible without a deterioration in 
Table 2. Calibrated parameter ranges and final fitted values used to simulate flow and ortho-phosphate loading in the upper Olifants catchment.

\begin{tabular}{|c|c|c|c|}
\hline Parameter & Description & Range & $\begin{array}{l}\text { Fitted } \\
\text { value }\end{array}$ \\
\hline \multicolumn{4}{|c|}{ Flow } \\
\hline $\mathrm{CN} 2^{1}$ & SCS runoff curve number & $0.81-1.13$ & 0.9 \\
\hline ALPHA_BF & Baseflow alpha factor (days) & $0.44-1.35$ & 0.76 \\
\hline GW_DELAY & Groundwater delay time (days) & $0-314$ & 214 \\
\hline GWQMN & $\begin{array}{l}\text { Threshold depth of water in the shallow aquifer for } \\
\text { return flow to occur }\left(\mathrm{mm} \mathrm{H}_{2} \mathrm{O}\right) \text {. }\end{array}$ & $2482-7457$ & 3568 \\
\hline REVAPMN & $\begin{array}{l}\text { Threshold depth of water in the shallow aquifer for } \\
\text { percolation to the deep aquifer to occur }\left(\mathrm{mm} \mathrm{H}_{2} \mathrm{O}\right) \text {. }\end{array}$ & $87-363$ & 157 \\
\hline GW_REVAP & Groundwater revap coefficient & $(0.16)$ & 0.16 \\
\hline ESCO & Soil evaporation compensation factor & $0-0.62$ & 0.02 \\
\hline CH_N2 & Manning $\mathrm{n}$ value for the main channel & $0.07-0.22$ & 0.19 \\
\hline ALPH_BNK & Baseflow alpha factor for bank storage (days) & $0-0.55$ & 0.09 \\
\hline SOL_AWC & $\begin{array}{l}\text { Soil available water storage capacity } \\
\left(\mathrm{mm} \mathrm{H} \mathrm{H}_{2} \mathrm{O} / \mathrm{mm} \text { soil }\right)\end{array}$ & $0.61-1.14$ & 0.97 \\
\hline SHALLST & Initial depth of water in the shallow aquifer & $60-687$ & 489 \\
\hline DEEPST & Initial depth of water in the deep aquifer & $218-2073$ & 1733 \\
\hline \multicolumn{4}{|c|}{ Ortho-phosphate ${ }^{2}$} \\
\hline $\mathrm{BC} 4$ & $\begin{array}{l}\text { Rate of constant decay of organic phosphorus to } \\
\text { dissolved phosphorus ( } 1 / \text { day) }\end{array}$ & & 0.05 \\
\hline USLE_P & USLE equation support practice factor & & 0.5 \\
\hline $\mathrm{RS} 2$ & $\begin{array}{l}\text { Benthic sediment source rate for OP in the reach at } \\
20^{\circ} \mathrm{C}\left(\mathrm{mg} \mathrm{OP} \mathrm{m}^{-3} \text { day }^{-1}\right)\end{array}$ & & 0.08 \\
\hline $\mathrm{AI} 2$ & Fraction of algal biomass that is phosphorus $\left(\mathrm{mg} \mathrm{P} \mathrm{mg}^{-1}\right)$. & & 0.16 \\
\hline PPERCO & Phosphorus percolation coefficient $\left(10 \mathrm{~m}^{3} \mathrm{Mg}^{-1}\right)$ & & 15.1 \\
\hline PHOSKD & Phosphorus soil partitioning coefficient $\left(\mathrm{m}^{3} \mathrm{Mg}^{-1}\right)$ & & 159 \\
\hline
\end{tabular}

another. Based on these criteria, the final parameter ranges identified after the second iteration were considered to be the calibrated parameter ranges providing the best simulation solution for the observed data at all calibration stations (Table 2).

In addition to the uncertainty parameters, further goodness of fit was quantified by the Nash-Sutcliffe (NS) coefficient between observed data and the best simulation identified by the SUFI-2 algorithm. The NS coefficients range from infinity to 1 . If the NS coefficients values are less than or close to 0 , the model simulation is taken as an indication of poor or unacceptable performance. The closer the values get to 1 , the more perfect the model simulation. Moriasi et al. (2007) indicate that a value greater than 0.5 for these variables constitutes an acceptable simulation model. Percent bias (PBIAS) is the average tendency of the simulated data to be larger or smaller than their observed counterparts (Moriasi et al.,
2007), and was also used to compare model outputs. For flow, PBIAS statistics indicating variation (a) between 15 and $25 \%$, (b) between 10 and $15 \%$ and (c) less than $10 \%$ are considered satisfactory, good and very good, respectively.

Considering that OP loads were estimated from infrequent monitoring data, we did not anticipate a good temporal comparison between monthly measured and predicted loads. It was however important that predicted loads fell within the range of measured loads. Calibration of parameters influencing OP loading was performed manually and only the PBIAS statistic was used to evaluate model predictions, with the emphasis on achieving a good comparison between average measured and predicted loads. For nutrient loads, PBIAS statistics indicating variation (a) between 40 and $70 \%$, (b) between 25 and $40 \%$ and (c) less than $25 \%$ are considered satisfactory, good and very good, respectively (Moriasi et al., 2007). 


\subsection{Model validation}

Model validation was performed by comparing simulated data to measured data retrieved from additional DWA monitoring stations (validation stations) located within the catchment (Fig. 1). Measured data from these validation stations were not used to calibrate the model. The same statistics used in assessing model calibration were used to assess model validation.

\subsection{Model application}

The calibrated model was used (a) to predict monthly and mean annual OP loading in the upper Olifants catchment, (b) to identify important sub-catchments responsible for high loading of OP, and (c) to estimate OP loading and concentrations in the four large reservoirs located in the catchment. Simulated monthly and mean annual OP concentrations were compared to available measured data (DWA, 2011a) from each of the reservoirs to determine model accuracy. In addition, two point source load reduction scenarios were simulated by reducing OP effluent concentrations (and derived loads) at each STW from $4 \mathrm{mg} \mathrm{L}^{-1}$ to 1 (current national phosphate effluent standard) and $0.1 \mathrm{mgL}^{-1}$, respectively. The effect of these reduction scenarios was evaluated by comparing predicted mean annual OP concentrations (for each year from 2002 to 2010) to OP water quality guidelines (DWAF, 1996) that identify thresholds associated with a trophic status (i.e. oligotrophic, mesotrophic, eutrophic and hyper-eutrophic). Each simulation for each scenario generated a load prediction and associated mean annual OP concentration for 9 annual time steps (2002 to 2010), with each time step accounting for prevailing hydrological conditions for that year. The data points for all scenarios (27 in total) were analysed by linear regression (using STATISTICA, version 12) and the associated $95 \%$ prediction limits were used to identify the range of OP loads that would ensure that mean annual OP concentrations in each reservoir would remain within a specific trophic status.

\section{Results and discussion}

\subsection{Flow simulations}

In general, flow simulations at calibration stations compared well to measured flow records and simulated monthly maximum flow volumes were similar to maximum volumes measured at flow gauging stations across the catchment (Fig. 2). The $r$ factor for calibration and validation stations for most catchment areas was below 1, indicating low uncertainty associated with model predictions. Stations located in the Wilge catchment (B2H014 and B2H007) area had $r$ factor values above 1 , indicating higher uncertainty associated with model outputs. The proportion of measured data bracketed by the 95 PPU band was relatively high for B1H004, B1H005
Table 3. Uncertainty and goodness of fit statistics for monthly flow and ortho-phosphate loading at calibration and validation stations in the upper Olifants catchment, South Africa.

\begin{tabular}{lrcrr}
\hline \multicolumn{5}{c}{ Calibration stations } \\
\cline { 2 - 5 } & B1H004 & B1H005 & B1H012 & B2H014 \\
\hline \multicolumn{5}{c}{ Flow } \\
\hline factor & 0.62 & 0.19 & 0.56 & 0.79 \\
$r$ factor & 0.48 & 0.28 & 0.64 & 1.98 \\
NS & 0.79 & 0.49 & 0.56 & 0.18 \\
PBIAS & 21.53 & 12.80 & 1.36 & 36.08 \\
\hline \multicolumn{5}{c}{ Ortho-phosphate } \\
\hline PBIAS & -19 & -41.45 & 2.40 \\
\hline \multicolumn{5}{c}{ Validation stations } \\
\cline { 2 - 5 } & B1H002 & B1H019 & B1H021 & B2H007 \\
\hline \multicolumn{5}{c}{ Flow } \\
\hline$p$ factor & 0.25 & 0.24 & 0.16 \\
$r$ factor & 0.40 & 0.35 & 0.30 & 0.89 \\
NS & 0.50 & 0.45 & 0.42 & 0.31 \\
PBIAS & 19.86 & -17.43 & 6.50 & 13.49 \\
\hline & \multicolumn{5}{c}{ Ortho-phosphate } \\
\hline PBIAS & 36.94 & -15.67 & -3.19 & 56.73 \\
\hline
\end{tabular}

and $\mathrm{B} 2 \mathrm{H} 014$. Apart from the $\mathrm{B} 2 \mathrm{H} 014$ area, NS statistics for all calibration stations were above 0.49 , indicating a satisfactory simulation (Table 3). The NS for the B1H004 area was particularly good (0.79). PBIAS statistics for these calibration stations were also considered to be satisfactory, falling below $25 \%$, with good and very good values obtained for B1H005 and B1H012, respectively. NS and PBIAS values for $\mathrm{B} 2 \mathrm{H} 014$ were poor (below 0.5 and above $25 \%$, respectively). With the exception of B2H014, NS statistics for the validation stations were slightly lower than for calibration stations across (Table 3). PBIAS statistics were slightly better at validation stations than at calibration stations.

Results therefore indicate that the model provides a satisfactory representation of flow characteristics in the upper Olifants catchment. The SWAT model has been successfully applied to simulate hydrology in other African countries (Baker and Miller, 2013; Schuol et al., 2008), as well as on the catchment (Andersson et al., 2011; Govender and Everson, 2005) and national scale (Andersson et al., 2012) in South Africa. The hydrological results of this paper therefore provide further evidence of the applicability of the SWAT model in a wide range of climatic and geographical conditions. Discrepancies between predicted and measured flows are most likely related to input uncertainty associated with rainfall data (Andersson et al., 2012). The upper Olifants catchment falls within a summer rainfall region which is 

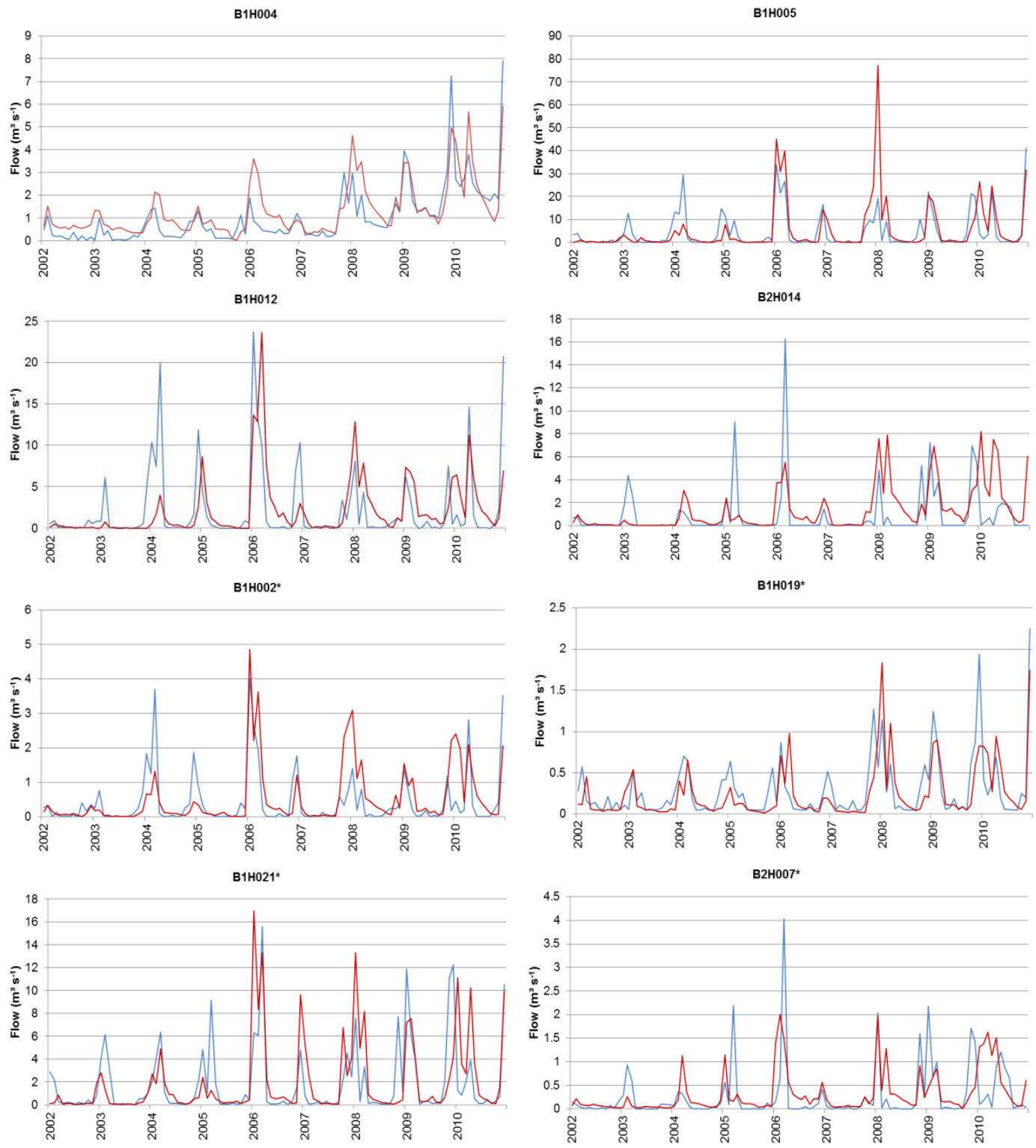

Figure 2. Predicted (red lines) and measured (blue lines) monthly flow at calibration and corresponding validation (indicated by *) monitoring stations located in the upper Olifants catchment.

characterised by isolated, scattered thunder showers. This results in highly variable rainfall patterns across the catchment. For example, peak flows were generally over-predicted during 2002 and 2003, particularly at B1H012 and B1H005, where rainfall monitoring stations were absent further up in their respective catchments. In these instances, SWAT retrieves rainfall data from the weather station in closest proximity to the sub-catchment (e.g. weather stations located close to Delmas and Middelburg) which have a good possibility of not being representative of rainfall conditions further upstream. Flow stations in closer proximity to weather stations (e.g. B1H002, B1H004 and B1H019) did not show such great discrepancies between measured and simulated flows during 2002 and 2003. The poor performances at B2H014 and B2H007 may also indicate that the hydrological processes in this part of the catchment may be fundamentally different from the rest of the catchment, and a separate calibration procedure for this part of the catchment may have been more appropriate.

\subsection{Phosphate loads}

Whilst flow is measured daily, water quality samples are collected far less frequently (from once a month to once a week). Given the large time periods between water quality sampling, there is thus a large degree of uncertainty associated with 
the calculation of measured monthly phosphate loads. However, for this modelling exercise, the primary objective was to simulate realistic average differences in OP loads originating from sub-catchments as opposed to simulating temporally accurate loads. In this context, the difference between mean annual measured and predicted loads was considered to be an acceptable form of evaluating model performance. Mean annual loads were calculated by summing monthly loads for a year and determining the annual average for the years 2002 to 2010. In this respect, PBIAS values at calibration stations indicated that the average tendencies of simulated monthly loads to be greater or smaller than measured loads were within the range of $40 \%(-41.45 \%$ at B1H005), which is an indication of good model performance (Table 3 ). Similar model performance was observed at the three validation stations, with very good performance observed at B1H021. These results are further supported by the comparison of mean annual measured and predicted loads at the calibration and validation stations (Fig. 3). For most stations there was a very good comparison, indicating that the model can successfully discriminate between total contributions of OP loading across the catchment. Importantly, there was a mix of point and nonpoint source contributions upstream of monitoring stations (e.g. no STWs were located upstream of B1H002, B1H019 and B2H007), and the favourable comparisons indicate that the model appears to account for contributions from these two sources accurately. This further indicates that $4 \mathrm{mg} \mathrm{L}^{-1}$ was a reasonable estimate of current effluent concentrations from STWs. Mean annual OP loads generated by each sub-catchment are presented in Fig. 4. The map clearly identifies sub-catchments responsible for high annual OP loading. STWs clearly contribute a significant proportion of OP to mean annual loads. In particular, STWs located in the upper reaches of the Wilge and Steenkoolspruit and lower reaches of the Klein Olifants River contribute high loads to the catchment.

No other studies have applied SWAT to predict nutrient input in South Africa, and only one other example exists for the rest of Africa. Kimwaga et al. (2012) implemented the model to predict the effectiveness of best management practices in reducing nonpoint-source pollution to Lake Victoria; however, no calibration of the model simulations was performed. Results of this study therefore represent one of the first to be conducted in South Africa and indeed Africa. A number of other studies have successfully applied SWAT to predict total phosphorus and nitrate loading (Grizzetti et al., 2003; Lam et al., 2010; Poudel et al., 2013; Ullrich and Volk, 2009). Fewer studies have however focused on the prediction of OP loads. In fact, a study by Daloğlu et al. (2012) which modelled long-term loading of dissolved reactive phosphorus (DRP) to Lake Erie is claimed to be the first long-term detailed analysis of DRP using SWAT. Results of this study therefore lend further support to the ability of the model to make realistic predictions of OP loading in large catchments. Considering the importance of OP in driving eutrophication

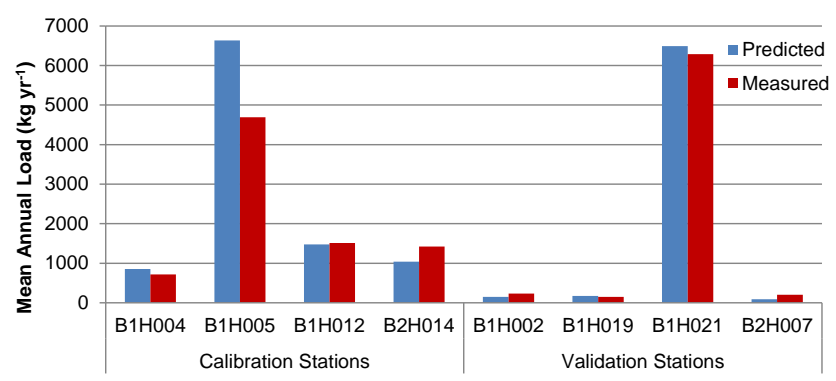

Figure 3. Predicted and observed mean annual ortho-phosphate loads at calibration and validation monitoring stations located in the upper Olifants catchment from 2002 to 2010.

in lakes and reservoirs (Reynolds and Davies, 2001), the implication of these results is that the model can be used to estimate the impact of different management scenarios on the trophic status in reservoirs in the catchment.

\subsection{Point source vs. nonpoint source contributions}

PBIAS statistics indicated that simulated OP concentrations in the four reservoirs were within an acceptable range of measured concentrations, particularly in the Witbank and Bronkhorstspruit reservoirs (Fig. 5). Temporal patterns of OP concentrations in the Bronkhorstspruit reservoir in particular are indicative of point source loading, with concentrations increasing markedly during the drier winter months when dilution of point source inputs is lower (Jarvie et al., 2006). The least accurate simulations were for Middelburg Dam, with the model under-predicting OP concentrations by approximately $50 \%$. This contradicts the results of the calibration procedure where model simulation compared well with measured simulation at B1H012. This discrepancy in the reservoir indicates that there is possibly an additional source of OP entering the reservoir after the calibration station that has not been accounted for in the model setup. Further investigation revealed that effluent from one of the largest feedlots in the catchment (annual throughput of 140000 head of cattle) was found to enter a tributary that flows directly into the Middelburg reservoir. The feedlot had not been accounted for in the model setup. Feedlots are known to contribute high loads of OP to aquatic systems (Kleinman et al., 2002) and could thus account for the discrepancy observed in this study. This example also serves to highlight the value of models in helping to understand or interrogate a catchment better when discrepancies between measured and predicted values occur. Future refinement of the model would need to take these potentially significant sources into account. For all reservoirs, measured OP concentrations were not well simulated by the model from 2008 onwards, with measured concentrations being considerably lower than simulated predictions. No obvious modelling errors could be detected that could account for this difference. The discrepancy could possibly be related to the inability of the model to simulate nutrient cycling 


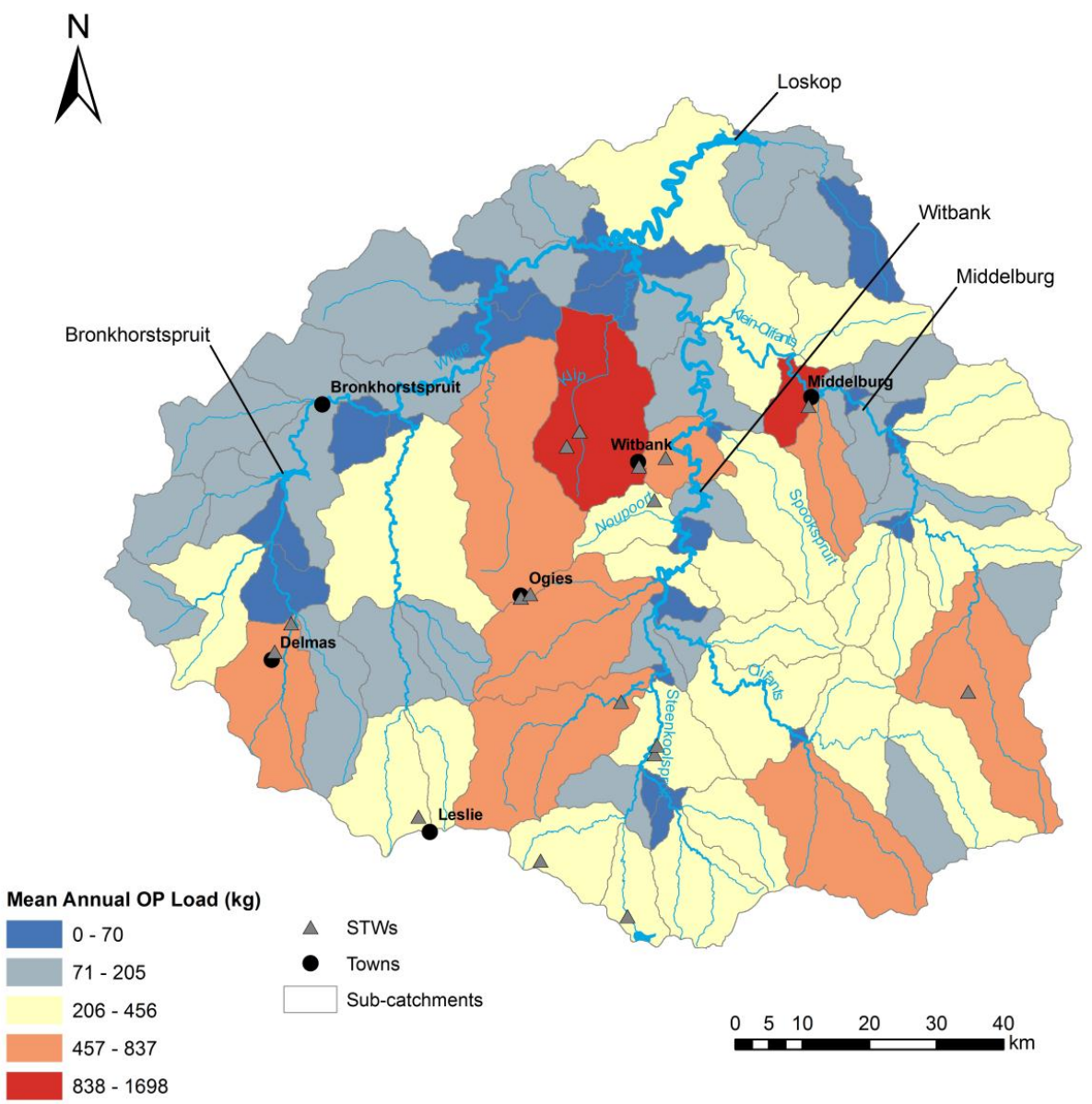

Figure 4. Mean annual OP (ortho-phosphate) loads generated by each sub-catchment of the upper Olifants River catchment from 2002 to 2010.

associated with the production of algal blooms in the reservoir. For example, the first large algal bloom recorded in the Loskop reservoir was in 2007, after which time blooms have re-occurred on an annual basis (Dabrowski et al., 2013). Subsequent monitoring in the reservoir revealed very low concentrations of OP associated with algal blooms - presumably due to uptake of OP to facilitate growth of algae (Dabrowski et al. 2013). The fact that these blooms occurred near the inflow of the reservoir (in the lacustrine zone) and that monitoring takes place at the dam wall could suggest that algal blooms may intercept OP concentrations and deplete levels before they reach the dam wall. None of the other reservoirs has been studied in sufficient detail to determine whether similar processes occur. As all reservoirs showed very similar declines in OP concentrations, all starting at the same time, analytical error can also not be ruled out.

In addition to monthly simulations, mean annual predicted OP concentrations compared well with observed values, with the exception of the Middelburg reservoir, where concentrations were under-predicted for possible reasons explained above (Fig. 6). Simulations excluding the input of point sources from STWs allowed for the quantification of the contribution of nonpoint sources to mean annual OP loads at each of the reservoirs included in the analysis. Results indicate that point sources and nonpoint sources affect the reservoirs differently. The Bronkhorstspruit and Loskop reservoirs are heavily impacted by point sources, which account for approximately 95 and $76 \%$ of the total OP loading on an annual basis (Fig. 7). The Witbank reservoir is also mainly impacted by point sources, but to a lesser degree than Loskop and Bronkhorstspruit (approximately $57 \%$ of mean annual total loading). In contrast, OP concentrations are mainly driven by nonpoint sources in the Middelburg reservoir. The impact of point sources on OP loading is most apparent when comparing the Middelburg and Bronkhorstspruit reservoirs. The Middelburg reservoir receives significantly lower loads of OP than the Bronkhorstspruit reservoir, even though the catchment area upstream of the Bronkhorstspruit reservoir is slightly smaller (Fig. 1). STWs in the catchment area of the Bronkhorstspruit reservoir are therefore responsible for significant loading of OP in this reservoir. The importance of point sources in the catchment can again be illustrated by 

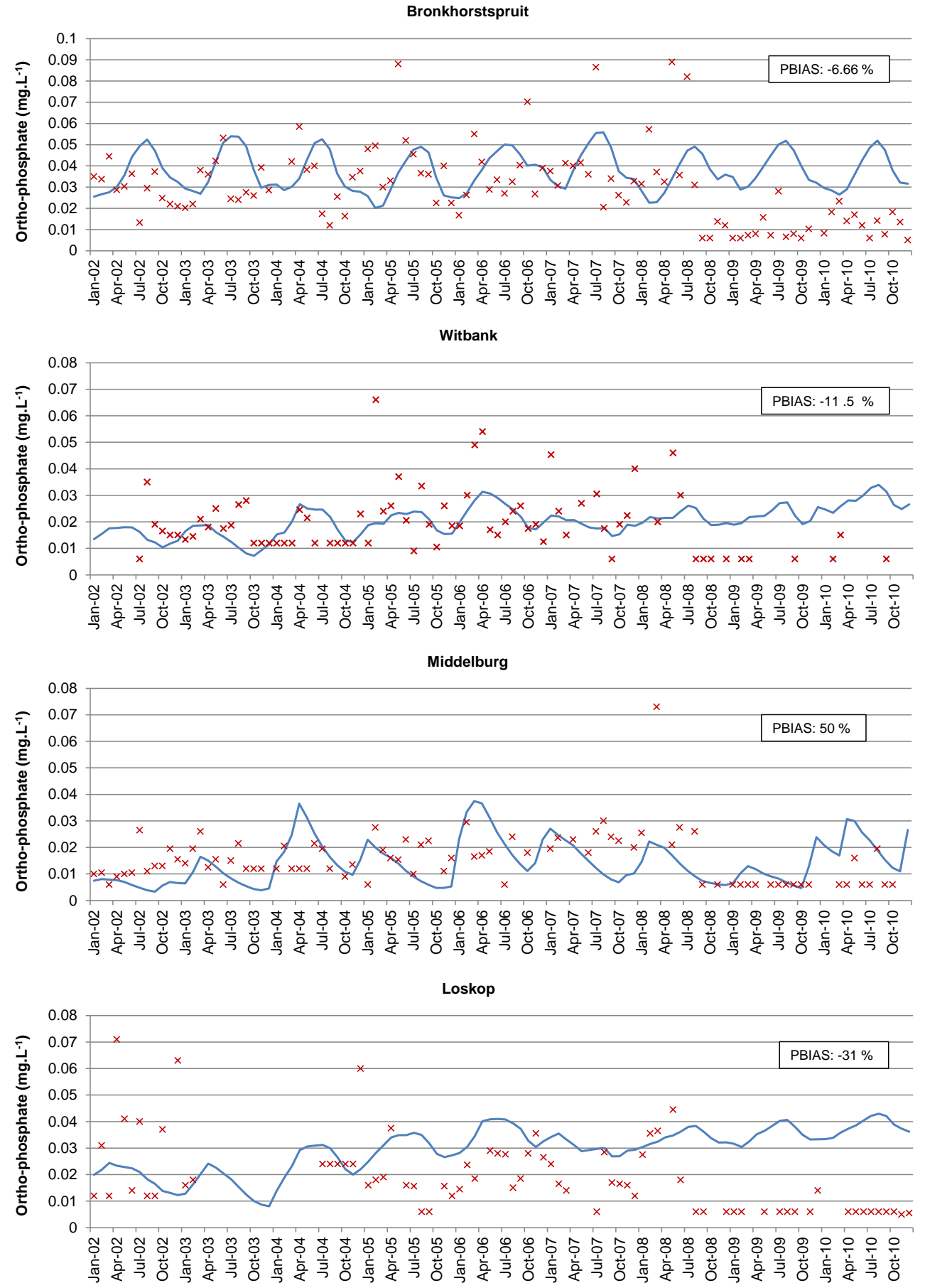

Figure 5. Predicted (solid lines) and observed $(x)$ ortho-phosphate concentrations in four reservoirs located in the upper Olifants River catchment.

the effect of the STW effluent reduction scenarios on loading in the reservoirs. Implementation of a $1 \mathrm{mg} \mathrm{L}^{-1}$ phosphate effluent standard would result in similar loading in the Middelburg and Bronkhorstspruit reservoirs (Fig. 7). This represents an approximate $77 \%$ reduction in loading in the Bronkhorstspruit reservoir. A similar effluent standard in the catchment area upstream of the Middelburg reservoir would have relatively little effect on loading, again emphasising the importance of nonpoint sources in this catchment. The effluent standard would result in an approximate $50 \%$ reduction in the Witbank reservoir, leading to a situation where point and nonpoint sources would contribute equally to OP loading 


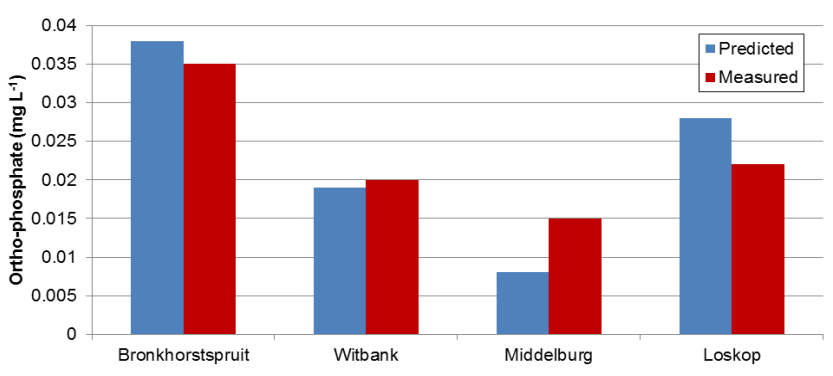

Figure 6. Predicted and observed mean annual ortho-phosphate concentrations in four reservoirs located in the upper Olifants catchment.

in the reservoir. The greatest reduction in terms of total load would be realised in the Loskop reservoir. A $1 \mathrm{mg} \mathrm{L}^{-1}$ effluent standard would result in a mean annual load of approximately $13900 \mathrm{~kg}$ (representing a $61 \%$ decrease), resulting in nonpoint sources becoming the most important driver of OP loading in this reservoir. A $0.1 \mathrm{mg} \mathrm{L}^{-1}$ effluent standard would result in further reductions in the Loskop and Bronkhorstspruit reservoirs, although the difference between the 0.1 and 1 scenarios is far smaller than the difference between the current and $1 \mathrm{mg} \mathrm{L}^{-1}$ scenarios. This indicates that the $1 \mathrm{mg} \mathrm{L}^{-1}$ scenario is potentially the most effective in making a large impact on OP reductions. Furthermore, the fact that nonpoint sources play more of a significant role in the $1 \mathrm{mg} \mathrm{L}^{-1}$ scenario indicates that the impact of alternative best management practices (e.g. riparian buffer strips, conservation tillage, fertiliser management, etc.) would need to be investigated in addition to the implementation of enhanced effluent treatment options. The extent of OP load reductions is also dependent on the desired state of the resource. In this respect the impact of OP loading on trophic status provides a valuable means of quantifying maximum allowable loading in a catchment. Such an approach is widely used in estimating total maximum daily loads (TMDLs) for pollutants in the USA (Borah et al., 2006).

\subsection{Impact of OP effluent standard scenarios on trophic status}

Minimising phosphate loads into aquatic ecosystems is key to combating eutrophication (Carpenter, 2008; Schindler et al., 2008). The influence of the effluent treatment scenarios on mean annual OP loading and concentrations can be seen in Fig. 8. The predictions for each year for each scenario are plotted for each reservoir. OP loading was a significant $(p<0.05)$ predictor of OP concentrations in all four reservoirs. Nielsen et al. (2013) observed a similar linear relationship between SWAT-generated phosphate loading and total phosphate concentrations in a reservoir in China. The regression and $95 \%$ prediction limits allow for the estimation of annual loading limits that ensure mean annual OP concentrations fall below certain trophic status indicators. The

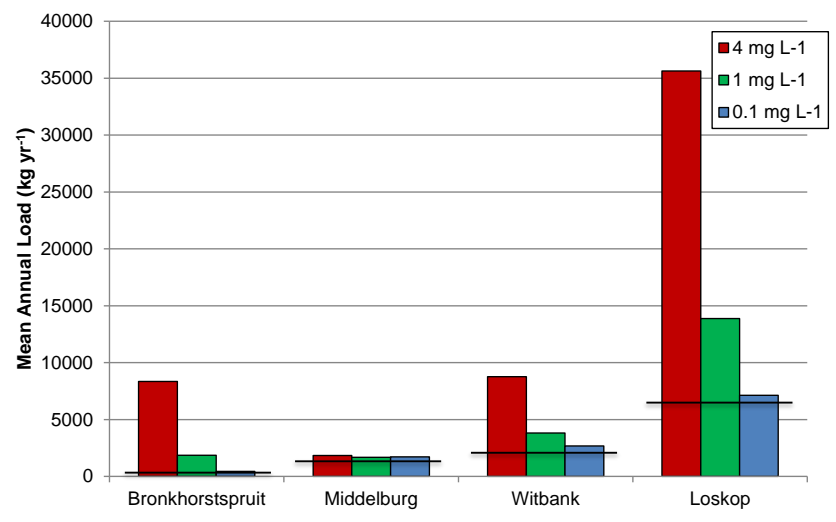

Figure 7. Mean annual OP loads associated with three STW effluent scenarios entering four reservoirs in the upper Olifants catchment (horizontal lines indicate nonpoint source contributions to mean annual OP loads per reservoir).

simulated mean annual concentrations and the corresponding trophic status of the current effluent scenario indicate that the Bronkhorstspruit and Loskop reservoirs fall within a eutrophic category, while the Witbank and Middelburg reservoirs fall predominantly in a mesotrophic category. The predicted trophic status for each reservoir corresponds well to the trophic status derived for these reservoirs in other studies and long-term monitoring programmes (where other parameters indicative of trophic status are monitored). The National Eutrophication Monitoring Programme classified both the Loskop and Bronkhorstpruit reservoirs as eutrophic and the Witbank and Middelburg reservoirs as mesotrophic (DWA, 2013). Of all the reservoirs, Loskop has been the most intensively studied, and recent monitoring has confirmed the presence of large blooms of Microcystis cyanobacteria during the summer months (Dabrowski et al., 2013). Oberholster et al. (2010) state that the first major algal bloom in Loskop Dam was recorded in 2008 and suggested that the dam had switched to a eutrophic state. SWAT simulations indicate that both the 1 and $0.1 \mathrm{mg} \mathrm{L}^{-1}$ STW effluent scenarios would result in all mean annual OP concentrations falling below the eutrophic level, within the mesotrophic range. More specifically, a mean annual load reduction from the current scenario of 35600 to $22000 \mathrm{~kg}$ (a $38 \%$ decrease) would result in $95 \%$ of mean annual OP concentrations falling below the eutrophic category (Fig. 8). Implementation of a $1 \mathrm{mg} \mathrm{L}^{-1}$ effluent standard across the catchment would be more than sufficient to meet this objective. While eutrophication in large water bodies can be reversed by decreasing inputs of phosphorus, rates of recovery are highly variable among water bodies and often the eutrophic state persists and recovery is slow (Carpenter et al., 1998). This is largely because of the effective recycling of accumulated phosphates within the water body. However, a recent study found the Loskop reservoir to be sensitive to phosphorus loads and, together with the fact that trophic status was considered to be on the 

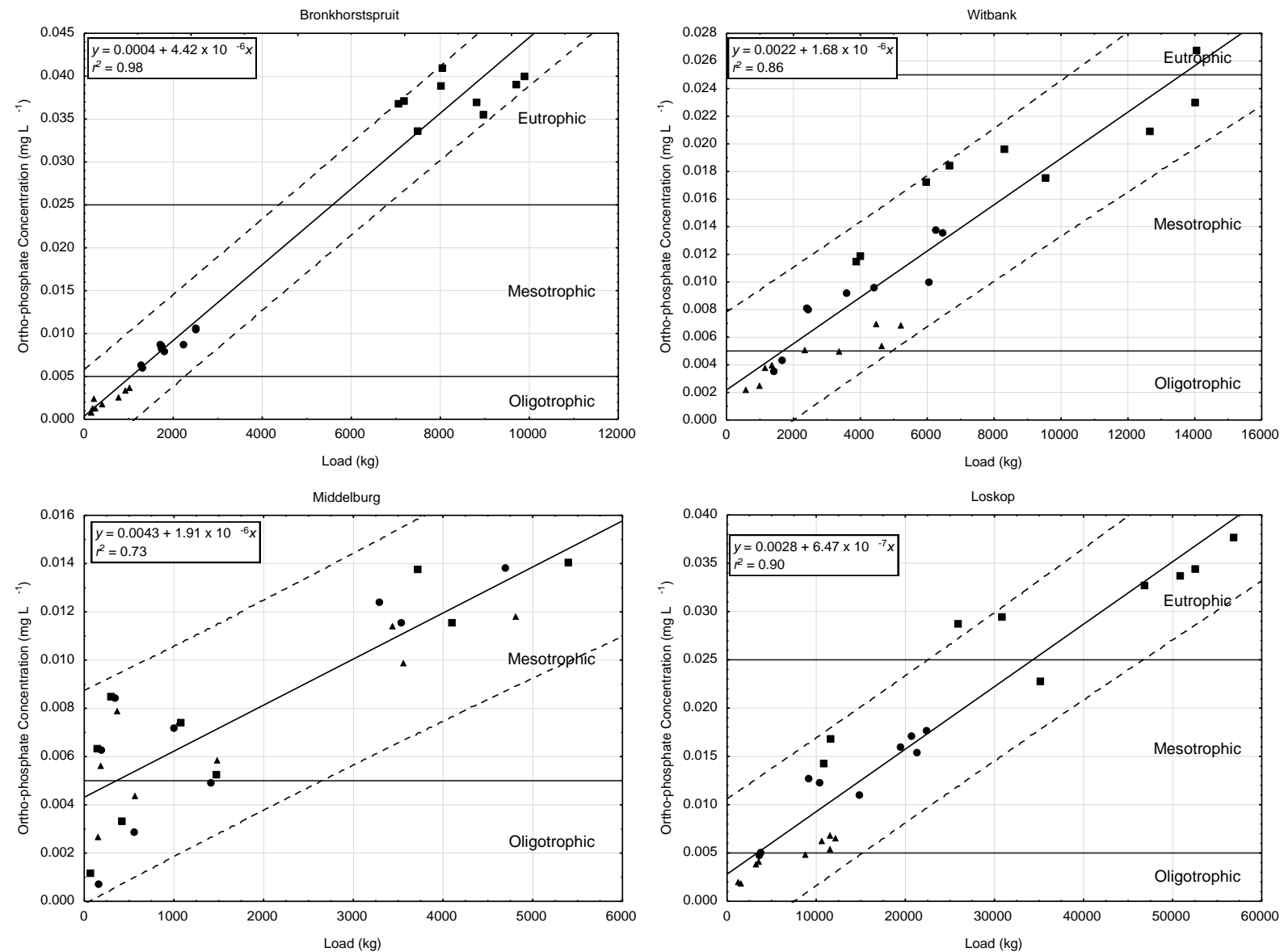

Figure 8. Linear regression plots of simulated loads and mean annual concentrations of ortho-phosphate associated with three sewage orthophosphate effluent standards $\left(4 \mathrm{mg} \mathrm{L}^{-1}-\mathbf{\square} ; 1 \mathrm{mg} \mathrm{L}^{-1}-\bullet ; 0.1 \mathrm{mg} \mathrm{L}^{-1}-\mathbf{\Delta}\right)$ in fours reservoirs located in the upper Olifants catchment. Each marker represents a simulation a specific year from the period 2002 to 2010 (dotted lines represent $95 \%$ prediction limits) (note the difference in scale on the $x$ axis).

threshold of eutrophic, load reductions would most likely result in a switch in trophic status to mesotrophic (Oberholster et al., 2013). The Bronkhorstspruit reservoir is most heavily affected by OP loading, with all current STW scenario predictions falling well within the eutrophic range. Implementation of either effluent reduction scenario would result in considerable decreases in annual loading and a trophic status that falls well within the mesotrophic range. An approximate $50 \%$ reduction in loads would result in $95 \%$ of mean annual loads, resulting in mean annual concentrations that fall within the mesotrophic range. The Witbank reservoir has only one mean annual concentration value within the eutrophic range and most mean OP concentrations fall within the mesotrophic range. The overlap in data points associated with the 0.1 and $1.0 \mathrm{mg} \mathrm{L}^{-1}$ scenarios indicates that the implementation of the strictest effluent guideline would not have a significant benefit over the $1.0 \mathrm{mg} \mathrm{L}^{-1}$ scenario. As highlighted previously, the influence of nonpoint sources in this catchment area would mask the added benefit derived from a $0.1 \mathrm{mg} \mathrm{L}^{-1}$ standard. Results indicate that the current mean annual loading of $8700 \mathrm{~kg}$ (Fig. 7), while sufficient for maintaining a mesotrophic status, is close to the load threshold of approximately $10000 \mathrm{~kg}$, above which less than $95 \%$ of mean annual OP values would fall within the mesotrophic range (Fig. 8). All mean annual OP concentrations fall well within the mesotrophic range at the Middelburg reservoir. Furthermore, there is a lot of overlap in mean annual OP concentrations associated with all STW scenarios (including the current scenario of $4 \mathrm{mg} \mathrm{L}^{-1}$ ). This is indicative of the fact that nonpoint source pollution is the primary driver behind OP concentrations in the dam, and any treatment options in STWs further upstream are unlikely to influence trophic status and OP concentrations to a significant extent. The regression model developed for the Middelburg reservoir provides an opportunity to estimate the potential load contributions from the feedlot to make up for the model under-prediction. A mean annual OP concentration of $0.015 \mathrm{mg} \mathrm{L}^{-1}$ (current measured concentration) would correspond to an average OP loading of $5750 \mathrm{~kg}$ (Fig. 8), which is almost $4000 \mathrm{~kg}$ higher than the current predicted load (Fig. 6). This implies 
that management of feedlot effluent in this catchment would make the most significant impact on OP loading for this reservoir.

\section{Conclusions}

This study comprises the first comprehensive application of SWAT to predict nutrient loading in a South African and African catchment and is one of the first in the world demonstrating the use of the model in predicting OP loading and associated concentrations in reservoirs. Overall the model was able to generate good spatial and temporal simulations of flow throughout the catchment, with validation stations generating similar goodness of fit statistics to calibration stations. This implies that the model can be highly beneficial in supporting catchment management through identification of drivers (i.e. point source over nonpoint source pollution) and specific source areas (i.e. sub-catchments) responsible for high OP loading. Furthermore, this study has demonstrated the application of the model in linking drivers of catchment pollution to potential ecological effects associated with pollution. This has an added benefit in that management options can be evaluated in terms of both estimated reductions in pollutants as well as the possible impact that these reductions will have on the aquatic ecosystem.

Discrepancies in flow profiles could largely be explained by the lack of weather data for large areas of the southern and southeastern parts of the catchment, and the addition of a weather station in this area would most likely improve flow and OP simulations in the catchment. The model did not provide good temporal predictions of OP loading at a monthly time step, which can be attributed to the paucity of monitoring data at calibration stations. There was however good correspondence between the range of simulated and measured values over a monthly time step, with little variation in the average tendency of simulated values to be larger or smaller than measured values. As a result, mean annual OP loading at calibration and validation stations compared very well with mean annual measured loads.

While model simulations can be improved significantly, it is important to note that, in contrast to the majority of studies that use a single site at the catchment outlet for calibrations, multiple un-nested sites were used in the calibration and validation procedure in this study. The observed simulations and associated statistics therefore provide a reasonable representation of hydrology and OP loading in multiple locations on varying spatial scales throughout the catchment area. The method used in this study therefore ensures greater confidence in the effectiveness of management interventions at most locations throughout the catchment. A drawback of this method is that calibration using multiple sites introduces more constraints on the process, making calibration challenging (White and Chaubey, 2005). For example, the poor statistics observed at monitoring stations in the
Wilge catchment (B2H007 and B2H014) indicate that the input parameters used to calibrate the model for the larger upper Olifants catchment are not a good representation of conditions in this part of the catchment, and separate input parameterisation of this section of the catchment may be necessary to account for hydrological variation. This was most likely an important contributing factor in limiting the number of SUFI-2 iterations that were able to be performed before a deterioration in objective functions was observed at some calibration stations.

Most importantly, the model was able to provide realistic estimates of OP concentrations in four different reservoirs of varying sizes, and allowed for the estimation of OP loading ranges that could be linked to trophic status categories. This study therefore provides promising evidence of applying the SWAT model in South African conditions and improving decision making with regards to formulating catchment management plans designed to improve ecological health and water quality through implementation of realistic management goals. In 1980, an OP standard of $1.0 \mathrm{mg} \mathrm{L}^{-1}$ was introduced in South Africa, with the specific aim of controlling eutrophication in sensitive catchments. The widespread occurrence of eutrophication in South African water bodies would indicate that this standard has apparently had little effect (Walmsley, 2000). However, these observations do not take into account the fact that many STWs across the country are most likely not meeting this standard in the first place. Nevertheless, past and recent studies have emphasised the importance of reducing the current OP effluent standard of $1 \mathrm{mg} \mathrm{L}^{-1}$ to a stricter standard of $0.1 \mathrm{mg} \mathrm{L}^{-1}$ (Dickens et al., 2010; Rossouw, 1990). Results from this study highlight that in some instances a $0.1 \mathrm{mg} \mathrm{L}^{-1}$ effluent standard is unlikely to have an effect if nonpoint sources are not adequately managed and that, at least for reservoirs in the upper Olifants catchment, a $1.0 \mathrm{mg} \mathrm{L}^{-1}$ effluent standard would result in mean annual OP concentrations in all reservoirs that fall below the eutrophic threshold.

Acknowledgements. This research was made possible through Parliamentary Grant funding received from the CSIR, Natural Resources and the Environment, project no. ECWH025.

Edited by: A. D. Reeves

\section{References}

Abbaspour, K. C.: SWAT-CUP4: SWAT Calibration and Uncertainty Programs - A Users Manual, Department of Systems Analysis, Swiss Federal Institute of Aquatic Science and Technology, Dübendorf, 2011.

Abbaspour, K. C., Yang, J., Maximov, I., Siber, R., Bogner, K., Mieleitner, J., Zobrist, J., and Srinivasan, R.: Modelling hydrology and water quality in the pre-alpine/alpine Thur watershed using SWAT, J. Hydrol., 333, 413-430, 2007. 
AGIS - Agricultural Geo-Referenced Information System: Natural Resources Atlas, available at: http://www.agis.agric.za/agisweb/ nr_atlas, last access: 15 November 2011.

Andersson, J. C. M., Zehnder, A. J. B., Wehrli, B., and Yang, H.: Improved SWAT model performance with time-dynamic Voronoi tessellation of climatic input data in Southern Africa, J. Am. Water Res. Assoc., 48, 480-493, 2012.

Andersson, J. C. M., Zehnder, A. J. B., Rockström, J., and Yang, H.: Potential impacts of water harvesting and ecological sanitation on crop yield, evaporation and river flow regimes in the Thukela River basin, South Africa, Agr. Water Manage., 98, 1113-1124, 2011.

ARC - Agricultural Research Council: Climate Services, Institute for Soil, Climate and Water, Agricultural Research Council, available at: http://www.arc.agric.za, last access: 15 October 2012 .

Arnold, J. G. and Fohrer, N.: SWAT2000: current capabilities and research opportunities in applied watershed modelling, Hydrol. Process., 19, 563-572, 2005.

Arnold, J. G., Srinivasan, R., Muttiah, R. S., and Williams, J. R.: Large area hydrologic modeling and assessment, Part i: model development, J. Am. Water Res. Assoc., 34, 73-89, 1998.

Ashton, P. J.: The demise of the Nile Crocodile (Crocodylus niloticus) as a keystone species for aquatic ecosystem conservation in South Africa: The case of the Olifants River, Aquat. Conserv., 20, 489-493, 2010.

ASTER - Advanced Spaceborne Thermal Emission And Reflection Radiometer/GDEM - Global Digital Elevation Model: Courtesy of the Ministry of Economy, Trade, and Industry (METI) of Japan and the United States National Aeronautics and Space Administration (NASA), available at: http://gdem.ersdac. jspacesystems.or.jp, last access: 20 November 2009.

Baker, T. J. and Miller, S. N.: Using the Soil and Water Assessment Tool (SWAT) to assess land use impact on water resources in an East African watershed, J. Hydrol., 486, 100-111, 2013.

Borah, D. K., Yagow, G., Saleh, A., Barnes, P. L., Rosenthal, W., Krug, E. C., and Hauck, L. M.: Sediment and nutrient modelling for TMDL development and implementation, T. ASABE, 49, 967-986, 2006.

Botha, H., van Hoven, W., and Guillett Jr., L. J.: The decline of the Nile crocodile population in Loskop Dam, Olifants River, South Africa, Water SA, 37, 103-108, 2011.

Carpenter, S. R.: Phosphorus control is crucial to mitigating eutrophication, P. Natl. Acad. Sci., 105, 11039-11040, 2008.

Carpenter, S. R., Caraco, N. F., Correll, D. L., Howarth, R. W., Sharpley, A. N., and Smith, V. H.: Nonpoint pollution of surface waters with phosphorus and nitrogen, Ecol. Appl., 8, 559-568, 1998.

Dabrowski, J., Oberholster, P. J., Dabrowski, J. M., Le Brasseur, J., and Gieskes, J.: Chemical characteristics and limnology of Loskop Dam on the Olifants River, in light of recent fish and crocodile mortalities, Water SA, 39, 675-686, 2013.

Dabrowski, J. M. and De Klerk, L. P.: An assessment of the impact of different land use activities on water quality in the upper Olifants catchment, Water SA, 39, 231-244, 2013.

Daloğlu, I., Cho, K. H., and Scavia, D.: Evaluating causes of trends in long-term dissolved reactive phosphorus loads to Lake Erie, Environ. Sci. Technol., 46, 10660-10666, 2012. de Villiers, S. and Thiart, C.: The nutrient status of South African rivers: concentrations, trends and fluxes from the 1970s to 2005, S. Afr. J. Sci., 103, 343-349, 2007.

Dickens, C. W. S., Graham, M., Simpson, D., Goliger, A., Dickens, J. K., Freese, S., Blignaut, J., and Quayle, L. M.: Investigation of the positive and negative consequences associated with the introduction of zero-phosphate detergents into South Africa, WRC Report No.: TT 446-10, Water Research Commission, Pretoria, South Africa, 2010.

DWA - Department of Water Affairs: Municipal wastewater treatment base information for targeted risk-based regulation: Mpumalanga Province, Pretoria, South Africa, 2009.

DWA - Department of Water Affairs: Green Drop Report 2009: South African Waste Water Quality Management Performance, Pretoria, South Africa, 2010.

DWA - Department of Water Affairs: Resource Quality Services Water Quality Data Exploration Tool, available at: http://www. dwa.gov.za/iwqs/wms/data/000key.asp, last access: 15 November 2011a.

DWA - Department of Water Affairs: Hydrological Services - Surface Water (Data, Dams, Floods and Flows, available at: http: //www.dwaf.gov.za/hydrology, last access: 15 November $2011 \mathrm{~b}$.

DWA - Department of Water Affairs: National Eutrophication Monitoring Programme, available at: http://www.dwaf.gov.za/iwqs/ eutrophication/NEMP/default.aspx, last access: 12 July 2013.

DWAF - Department of Water Affairs and Forestry: South African Water Quality Guidelines, Volume 7: Aquatic Ecosystems, Pretoria, South Africa, 1996.

DWAF - Department of Water Affairs and Forestry: National Water Resource Strategy, Pretoria, South Africa, 2004.

FAO: Fertilizer Use by Crops in South Africa, Food and Agriculture Organization of the United Nations, Rome, 2005.

Ferreira, S. M. and Pienaar, D.: Degradation of the crocodile population in the Olifants River Gorge of Kruger National Park, South Africa, Aquat. Conserv., 21, 155-164, 2011.

Gassman, P. W., Reyes, M. R., Green, C. H., and Arnold, J. G.: The soil and water assessment tool: historical development, applications, and future research directions, Center for Agricultural and Rural Development, Iowa State University, Iowa, 2007.

Govender, M. and Everson, C. S.: Modelling streamflow from two small South African experimental catchments using the SWAT model, Hydrol. Process., 19, 683-692, 2005.

Grizzetti, B., Bouraoui, F., Granlund, K., Rekolainen, S., and Bidoglio, G.: Modelling diffuse emission and retention of nutrients in the Vantaanjoki watershed (Finland) using the SWAT model, Ecol. Model., 169, 25-38, 2003.

Hart, M. R., Quin, B. F., and Nguyen, M. L.: Phosphorus runoff from agricultural land and direct fertilizer effects: a review, J. Environ. Qual., 33, 1954-1972, 2004.

Hobbs, P., Oelofse, S. H. H., and Rascher, J.: Management of environmental impacts from coal mining in the upper Olifants River catchment as a function of age and scale, Water Resour. Dev., 24, 417-431, 2008.

Huchzermeyer, K. D. A., Osthoff, G., Hugo, A., and Govender, D.: Comparison of the lipid properties of healthy and pansteatitis-affected African sharptooth catfish, Clarias gariepinus (Burchell), and the role of diet in pansteatitis outbreaks in the Olifants River in the Kruger National Park, South Africa, J. Fish Dis., 1-13, 2013. 
Jarvie, H. P., Neal, C., and Withers, P. J. A.: Sewage-effluent phosphorus: A greater risk to river eutrophication than agricultural phosphorus?, Sci. Total Environ., 360, 246-253, 2006.

Kimwaga, R. J., Mashauri, D. A., Bukirwa, F., Banadda, N., Wali, U. G., and Nhapi, I.: Development of best management practices for controlling the non-point sources of pollution around Lake Victoria using SWAT Model: A case of Simiyu catchment, Tanzania, Open Environ. Eng. J., 5, 77-83, 2012.

Kleinman, P. J. A., Sharpley, A. N., Moyer, B. G., and Elwinger, G. F.: Effect of mineral and manure phosphorus sources on runoff phosphorus, J. Environ. Qual., 31, 2026-2033, 2002.

Lam, Q. D., Schmalz, B., and Fohrer, N.: Modelling point and diffuse source pollution of nitrate in a rural lowland catchment using the SWAT model, Agr. Water Manage., 97, 317-325, 2010.

Lam, Q. D., Schmalz, B., and Fohrer, N.: The impact of Best Management Practices on water quality in a North German lowland catchment, Environ. Monit. Assess., 183, 351-379, 2011.

Liersch, S.: The Program pcpSTAT: User's Manual, available at: http://swat.tamu.edu/media/83150/manual_pcpSTAT.pdf (last access: July 2014), 2003.

Mainstone, C. P. and Parr, W.: Phosphorus in rivers - ecology and management, Sci. Total Environ., 282-283, 25-47, 2002.

Middleton, B. J. and Bailey, A. K.: Water Resources of South Africa, 2005 Study, WRC Report No. TT381/08. Water Research Commission, Pretoria, South Africa, 2008.

Moriasi, D. N., Arnold, J. G., Van Liew, M. W., Binger, R. L., Harmel, R. D., and Veith, T. L.: Model evaluation guidelines for systematic quantification of accuracy in watershed simulations, T. ASABE, 50, 885-900, 2007.

Neitsch, S. L., Arnold, J. G., Kiniry, J. R., Srinivasan, R., and Williams, J. R.: Soil and water assessment tool: User's Manual, TWRI Report TR-192, College Station, Texas, 2002.

Neitsch, S. L., Arnold, J. G., Kiniry, J. R., and Williams, J. R.: Soil and Water Assessment Tool Theoretical Documentation, Temple, Texas, 2005.

Nielsen, A., Trolle, D., Me, W., Luo, L., Han, B.-P., Liu, Z., Olesen, J. E., and Jeppesen, E.: Assessing ways to combat eutrophication in a Chinese drinking water reservoir using SWAT, Mar. Freshwater Res., 64, 475-492, 2013.

Oberholster, P. J. and Botha, A.-M.: Dynamics of phytoplankton and phytobenthos in Lake Loskop (South Africa) and downstream irrigation canals, Fundament. Appl. Limnol., 179, 169178, 2011.

Oberholster, P. J., Myburgh, J. G., Ashton, P. J., and Botha, A.M.: Responses of phytoplankton upon exposure to a mixture of acid mine drainage and high levels of nutrient pollution in Lake Loskop, South Africa, Ecotoxicol. Environ. Safe., 73, 326-335, 2010

Oberholster, P. J., Dabrowski, J., and Botha, A.-M.: Using modified multiple phosphorus sensitivity indices for mitigation and management of phosphorus loads on a catchment level, Fundament. Appl. Limnol., 182, 1-16, 2013.
Poudel, D. D., Lee, T., Srinivasan, R., Abbaspour, K., and Jeong, C. Y.: Assessment of seasonal and spatial variation of surface water quality, identification of factors associated with water quality variability, and the modeling of critical nonpoint source pollution areas in an agricultural watershed, J. Soil Wat. Conserv., 68, 155-171, 2013.

Reynolds, C. S. and Davies, P. S.: Sources and bioavailability of phosphorus fractions in freshwaters: a British perspective, Biol. Rev., 76, 27-64, 2001.

Rossouw, J. N.: The development of management orientated models for eutrophication control, WRC Report No. 174/1/90, Water Research Commission, Pretoria, South Africa, 1990.

SANBI - South African National Biodiversity Institute: National Land Cover 2009, available at: http://bgis.sanbi.org/landcover/ project.asp, last access: 20 November 2009.

Schindler, D. W., Hecky, R. E., Findlay, D. L., Stainton, M. P., Parker, B. R., Paterson, M. J., Beaty, K. G., Lyng, M., and Kasian, S. E. M.: Eutrophication of lakes cannot be controlled by reducing nitrogen input: results of a 37-year whole-ecosystem experiment, P. Natl. Acad. Sci., 105, 11254-11258, 2008.

Schuol, J. R., Abbaspour, K. C., Srinivasan, R., and Yang, H.: Estimation of freshwater availability in the West African subcontinent using the SWAT hydrologic model, J. Hydrol., 352, 30-49, 2008.

STATSSA - Statistics South Africa: Census of Agriculture Provincial Statistics 2002, Report No. 11-02-10, Pretoria, South Africa, 2006.

Ullrich, A. and Volk, M.: Application of the Soil Water Assessment Tool (SWAT) to predict the impact of alternative management practices on water quality and quantity, Agr. Water Manage., 96, 1207-1217, 2009.

van Ginkel, C. E.: Eutrophication: Present reality and future challenges for South Africa, Water SA, 37, 693-702, 2011.

Walker, W. W.: Simplified procedures for eutrophication assessment and prediction: User manual, Instruction Report W-96-2, US Army Engineer Waterways Experiment Station, Vicksburg, MS, 1996.

Walmsley, R. D.: Perspectives on eutrophication of surface waters: policy/research needs in South Africa, WRC Report No. KV129/00, Water Research Commission, Pretoria, South Africa, 2000.

White, K. L. and Chaubey, I.: Sensitivity analysis, calibration and validation for a multisite and multivariable SWAT model, J. Am. Water Res. Assoc., 41, 1077-1089, 2005.

Winchell, M., Srinivasan, R., Di Luzio, M., and Arnold, J.: ArcSWAT Interface for SWAT 2009, USDA Agricultural Research Service and Texas A\& M Blackland Research Center, Temple, Texas, 2010. 